seismicity 0.1 ; (IV) the extreme northern tip of North Island, average $1 \cdot 1$ earthquakes per year and relative seismicity 0.0 . In region $I$, the strongest shocks tend to congregate towards the east and south-east though the north-western part has the highest frequency for moderate or small shocks. The difference may be due to differences in the strength of crustal materials. In region II Taranaki is liable to semi-destructive shocks at infrequent intervals, "near" Auckland may have had violent shocks during 1835-36, and New Plymouth in 1819. In region III one semi-destructive shock between Mount Cook and Lake Wanaka has been definitely recorded though heavy shocks in the west coast sounds area have been mentioned in 1792, 1810 and $1826-27$.

Earthquakes within about $10^{\circ}$ of Wellington during May 1942 numbered 12. The greatest had intensity 4 (Rossi-Forel) on May 10, near Whakatane, and one on May 27 may have had intensity 3 at Upper Takaka. Two shocks on May 7 and May 21 respectively were felt at Rotorua. Additionally, five distant earthquakes were registered by the seismographs at Wellington, Christchurch, Auckland and Arapuni according to the provisional Bulletin $P-123$ published by the Dominion Observatory at Wellington.

\section{ORIGIN OF COSMIC RAYS}

A NEW hypothesis of the origin of cosmic rays and reports on its experimental testing in India and elsewhere are published in the Physical Review $(61,397$ and $407 ; 1942)$ by R. A. Millikan, H. V. Neher and W. H. Pickering. While retaining the fundamental basis of nuclear physics theories and transformations of rest mass into other forms of energy, former suggestions are reversed. The sun's heat is assumed to correspond with atom building going on in its interior, whereas cosmic rays are due to the complete annihilation process going on in interstellar space. The transformation of the rest mass of the atoms into cosmic-ray energy is postulated as complete instead of partial.

When the postulates are used, five definite cosmicray bands are predicted, each reaching the earth in a particular latitude, and four plateaux of unchanging cosmic-ray intensity, these plateaux being delineated by the latitudes of entrance of the successive bands. The bands are named as (i) a silicon band of energy $13 \cdot 2$ Bev., (ii) an oxygen-nitrogen band of mean energy $7 \cdot 1$ Bev., (iii) a carbon band of energy $5 \cdot 6$ Bev. and (iv) a helium band of energy 1.9 Bev.

To test these predictions it was necessary to measure directly vertical incoming cosmic-ray energies as a function of latitude. India is the most suitable place in the world for the most significant of the tests. While in India it takes 17 billion-volt, vertical, charged-particle rays to break through the blocking effect of the earth's magnetic field at the equator, about 13 billion only suffice on the other side of the earth in Peru.

A comparison of theory and experiment was made possible largely through generous support of the research by the Carnegie Corporation of New York, the Carnegie Institution of Washington and the India Meteorological Service. The results so far attained are the detection of the silicon band and the joint nitrogen-oxygen band, with less definite observation of the carbon and the helium bands.
The predicted values for latitudes and order of intensity are approximately of the same value as the observed. At least three of the four plateaux of constant cosmic-ray intensity were observed.

In the second paper, by Neher and Pickering, experimental details are given, although full description of the apparatus appears in the Review of Scientific Instruments under the title "A Cosmic-Ray Radio Guide" (13, 143; 1942). This instrument is a miniature radio-transmitter recording barometric pressure and atmospheric temperatures as well as the Geiger counter observations. By its aid, Geiger counter and electroscope observations were compared. The counter was found to give results very close to those of the electroscope and of comparable accuracy. When two or more counters are arranged as a cosmicray telescope, the radiation from a selected part of the sky only is recorded. Thus the energies recorded are delimited with considerably greater accuracy than by the use of the electroscope.

\section{FORTHCOMING EVENTS}

\author{
Tuesday, August 25
}

INSTITUTION OF CIVIL ENGINERRs (at Great George Street, Westminster, London, S.W.1), at 2.30 p.m.- Conference on "Civil Engineers and the Building Industry" (to be opened by Prof. C. E. Inglis, F.R.S.).

\section{APPOINTMENTS VACANT}

AppLICATIONS are invited for the following appointments on or before the dates mentioned:

Assistant to the Advisory OfFiogr in Plant Husbandry, and an ASSISTANT LECTURER IN THE DEPARTMENT OF BACTERIOLOGY The Secretary, West of Scotland Agricultural College, 6 Blythswood Square, Glasgow (August 28).

assistant to the Chief Researoh Offich of the Mentat ASSISTANT TO THE CHIEF RESEARCH OFFIOER OF THE MENTAL
DISEASE RESEARCH DEPARTMENT-The Secretary, The University, DISEASE RESEARCH DEPAR
Birmingham (September 1 ).

UNIVERSITY ChaIR of CHEMISTRY, tenable at the Royal Cancer Hospital-The Academic Registrar, University of London, Richmond College, Richmond, Surrey (September 1).

Physioal Chemist and a Mineralogist or Geo-chemist For RESEARCH WORK INTO MATERTALS AND PROCESSES OF THE CERAMIC INDCSTRIES-The Director of Research, British Pottery Research Association, Queens Road, Penkhull, Stoke-on-Trent.

Graduate (MAN or WOMAN) in ScIENCE or equivalent in Engineering, and a GRADEATE (MAN OR WOMAN) IN SCIENCE including Biology, and able to assist in General Subjects, at the Mexborough Schofieid Yorks.

\section{REPORTS and other PUBLICATIONS}

(not included in the monthly Books Supplement)

\section{Great Britain and Ireland}

Reports of the Council and Auditors of the Zoological Society of London for the Year 1941. Pp. 38. (London: Zoological Society of
[58

Proceedings of the Royal Society of Edinburgh. Section B (Biology), Vol. 61, Part 3, No. 22: Deflciency Effects of Ultra-violet Light in Drosophila melanogaster. By Dr. B. M. Slizynski. Pp. 297-315. (Edinburgh and London: Oliver and Boyd.) 1s.6d. [58

\section{Other Countries}

Commonwealth of Australia: Councll for Scientific and Industrial Research. Bulletin No. 144: Interference in a Wind-Tunnel of Octagonal Section. By G. K. Batchelor. Pp. 24. Bulletin No. 147: Enzootic Ataxia and Copper Deficiency of Sheep in Western Australia: By H. W. Bennetts and A. B. Beck. Pp. 52. Pamphlet No. 110 The Main Virus Diseases of the Potato in Victoria. By Dr. J. G.
Bald and A. T. Pugsley. Pp. $40+4$ plates. (Melbourne : Govern-
[287

[287 Indian Forest Bulletin No. 17 (Silviculture, New Series): A Note on Semal (Bombax malabaricum D.C.). By Jagdamba Prasad. Pp $\mathrm{v}+15+3$ plates. (Delhi : Manager of Publications.) 14 annas
18. 3 d. 